\title{
PENENTUAN KUALITAS AIR SALURAN PEMBUANGAN LIMBAH TAHU DI SUNGAI PENGGING BOYOLALI
}

\author{
Rian Adi Setia Rahman ${ }^{1}$, Imelda Fajriati ${ }^{1^{*}}$ \\ ${ }^{1}$ Program Studi Kimia, Fakultas Sains dan Teknologi, UIN Sunan Kalijaga Yogyakarta \\ Jalan Marsda Adisucipto No. 1, Yogyakarta, 55281, Indonesia \\ imelda.fajriati@uin-suka.ac.id
}

Artikel Info
Diterima
tanggal
04.08 .2020
Disetujui
publikasi
tanggal
30.04.2021
Kata kunci :
Tofu Waste,
Water
Quality,
Pengging
River$$
\text { p }
$$

ABSTRAK

Penentuan kualitas air pada Sungai Pengging Boyolali sebagai muara pembuangan limbah tahu telah dilakukan. Penelitian ini bertujuan untuk mengetahui kualitias air Sungai Pengging. Analisis meliputi penentuan suhu air contoh, pH, Total Dissolved Solid (TDS), Disolved Oksigen (DO), Biochemical Oxygen Demand (BOD), dan Chemical Oxygen Demand (COD). Metode pengambilan sampel menggunakan metode purposive sampling yang dilakukan pada 3 titik (titk 1, titik 2 dan titik 3) dengan mengikuti tata cara sampling dan analisis parameter air mengikuti SNI 066989.14-2004 dan SNI 6989.72-2009. Hasil penelitian menunjukkan bahwa contoh air pada pengambilan titik 2 relatif memiliki tingkat pencemaran lebih tinggi daripada 2 titik tempat pengambilan contoh air yang lain. Parameter pencemaran pada titik 2 diindikasikan oleh tingginya temperatur air $\left(29,05-30,1{ }^{\circ} \mathrm{C}\right)$, nilai TDS $(8,33-10,95$ $\mathrm{mg} / \mathrm{L})$, nilai COD dan BOD (71,5 dan 28,2 mg/L), serta nilai DO paling kecil $(0,11$ $0,16 \mathrm{mg} / \mathrm{L})$.
\end{abstract}

\section{ABSTRACT}

Determination of water quality in the Pengging Boyolali River as a tofu waste disposal channel has been carried out. This study aims to determine the quality of the Pengging River water. The analysis includes determining the sample water temperature, $\mathrm{pH}$, Total Dissolved Solid (TDS), Disolved Oxygen (DO), Biochemical Oxygen Demand (BOD), and Chemical Oxygen Demand (COD). The sampling method used was purposive sampling method which was carried out at 3 points (point 1, point 2 and point 3) by following the sampling procedure and water parameter analysis in SNI 06-6989.14-2004 and SNI 6989.72-2009. The results showed that the water samples at point 2 had a relatively higher level of pollution than the other 2 sampling points. Pollution parameters at point 2 are indicated by higher water temperature $\left(29.05-30.1{ }^{\circ} \mathrm{C}\right)$, TDS value $(8.33-10.95 \mathrm{mg} / \mathrm{L}), \mathrm{COD}$ and BOD values $(71.5$ and 28.2 $\mathrm{mg} / \mathrm{L})$, and the smallest DO value $(0.11-0.16 \mathrm{mg} / \mathrm{L})$. 


\section{PENDAHULUAN}

Industri tahu banyak berkembang di banyak wilayah di Indonesia. Pada umumnya tahu diproduksi dalam skala industri rumah tangga dengan teknologi pengolahan cukup sederhana. Teknologi pengolahan yang sederhana inilah yang menyisakan beberapa permasalahan, antara lain permasalahan limbah tahu yang belum tertangani maksimal (Febrian, 2020). Banyak pembuangan limbah pabrik tahu ke aliran sungai tanpa dilakukan pengolahan terlebih dahulu (Nurhasan dan Pramudyanto, 1991).

Limbah tahu adalah bahan sisa yang tidak digunakan kembali akibat kegiatan produksi tahu yang sudah tidak dimanfaatkan lagi. Komponen utama limbah industri tahu adalah senyawa protein, di mana relatif cepat mengalami pembusukan apabila terbuang di alam bebas. Limbah tahu dapat berbentuk padatan berupa ampas kedelai serta berbentuk cairan berupa air sisa perendaman kedelai yang tidak menggumpal, berwarna kuning muda dan berbau busuk (Yudhistira, 2016).

Pencemaran air sungai diindikasikan dengan perubahan sifat fisik dan kimia air sungai seperti perubahan warna air dan munculnya bau tidak sedap yang berasal dari gas sulfur atau gas $\mathrm{NH}_{3}$ akibat proses fermentasi dan peruraian limbah organik. Pembusukan dan pengendapan dari ampas limbah tahu dapat mengubah nilai kadar Biochemical Oxygen Demand (BOD), serta Chemical Oxygen Demand (COD). Oleh karena itu keberadaan limbah tahu dapat menurunkan daya dukung lingkungan pada perairan tersebut (Adeko, 2018).

Sungai Pengging berada di Kecamatan Banyudono Kabupaten Boyolali terindikasi mempunyai tingkat pencemaran cukup tinggi. Hal ini karena terdapat pabrik tahu yang secara langsung membuang limbahnya ke badan Sungai Pengging. Pengaruh limbah yang terbuang dalam aliran sungai dapat ditentukan dengan parameter kualitas air seperti suhu, $\mathrm{pH}$, Total Dissolved Solid (TDS), Disolved Oksigen (DO), Biochemical Oxygen Demand (BOD), dan Chemical Oxygen Demand (COD) (Pradana, 2018).

Berdasarkan uraian di atas, penelitian ini bertujuan untuk mengetahui kualitas air Sungai Pengging dengan menggunakan parameter suhu, $\mathrm{pH}$, TDS, DO, BOD, dan COD. Nilai parameter tersebut selanjutnya disesuaikan dengan cakupan parameter dalam Standar Nasional Indonesia (SNI) serta dikaji berdasarkan standar baku mutu air limbah sebagaimana dalam Peraturan Menteri Lingkungan Hidup Republik Indonesia No.5 Tahun 2014 (Tabel 1). 
Tabel 1. Baku mutu air limbah sesuai Peraturan Menteri Lingkungan Hidup Republik Indonesia No.5 Tahun 2014

\begin{tabular}{c|cc}
\hline \multirow{2}{*}{$\begin{array}{c}\text { Parameter Kualitas } \\
\text { Air }\end{array}$} & \multicolumn{2}{|c}{ Pengelolaan Kedelai } \\
\cline { 2 - 3 } & $\begin{array}{c}\text { Tahu } \\
\text { Kadar }(\mathrm{mg} / \mathrm{L})\end{array}$ & $\begin{array}{c}\text { Tempe } \\
\text { Kadar }(\mathrm{mg} / \mathrm{L})\end{array}$ \\
\hline BOD & 150 & 150 \\
COD & 300 & 300 \\
TSS & 200 & 100 \\
pH & & $6-9$ \\
\hline
\end{tabular}

Satuan kuantitas air limbah adalah $\mathrm{m}^{3} /$ ton bahan baku

Hasil penelitian ini dapat menggambarkan kondisi perairan sungai khususnya yang terindikasi menjadi muara saluran pembuangan limbah tahu, sehingga potensi pencemaran lebih lanjut dapat dicegah oleh semua pihak.

\section{METODE}

\section{Alat dan Bahan}

Alat yang digunakan pada penelitian ini adalah pengukur suhu merk Eutech Instruments CyberScan, pH meter merk Ohaus Starter 300, botol Winkler, seperangkat alat gelas, neraca analitik merk Sartorius, Spektrofotometer UV-Vis merk Fujitsu, labu digestion dan pemanas (heating block). Bahan yang digunakan pada penelitian ini adalah garam $\mathrm{MnSO}_{4} .4 \mathrm{H}_{2} \mathrm{O}$; Basa $\mathrm{NaOH}$ dan $\mathrm{KOH}, \mathrm{Na}$-iodida (NaI), indikator amilum, Natrium Azida $\left(\mathrm{NaN}_{3}\right)$, Natrium Tiosulfat $\left(\mathrm{Na}_{2} \mathrm{~S}_{2} \mathrm{O}_{3} .5 \mathrm{H}_{2} \mathrm{O}\right)$, Kalium Bikromat $\left(\mathrm{K}_{2} \mathrm{Cr}_{2} \mathrm{O}_{7}\right)$, Akuades, larutan Buffer Fosfat, larutan Kalium Iodida $10 \%$, Asam Asetat $\left(\mathrm{CH}_{3} \mathrm{COOH}\right)$, pereaksi Asam Sulfat $\left(\mathrm{H}_{2} \mathrm{SO}_{4}\right)$, dan Asam Sulfamat $\left(\mathrm{NH}_{2} \mathrm{SO}_{3} \mathrm{H}\right)$, serta larutan baku Kalium Hidrogen Ftalat $\left(\mathrm{HOOCC}_{6} \mathrm{H}_{4} \mathrm{COOK}\right)$.

\section{Prosedur}

\section{Teknik Sampling}

Wadah berupa botol air mineral disiapkan dan dibilas dengan air contoh yang akan diambil. Botol dimasukkan ke sungai dengan tutup botol dibuka sehingga air sampel dapat masuk ke dalam botol sampai terisi penuh. Botol segera ditutup ketika air telah terisi penuh dan posisi botol masih berada di dalam air. Pengambilan air dilakukan pada jarak 25 meter sebelah 
barat dari sumber pembuangan limbah, 0 meter dari sumber pembuangan limbah, dan 25 meter sebelah timur dari pembuangan limbah, yang masing-masing pada jarak $30 \mathrm{~cm}$ dari tepi sungai sebelah utara dan kedalaman $3 \mathrm{~cm}$ (sesuai dengan SNI 6989.57:2008) tentang tata cara Teknik sampling.

\section{Penentuan DO}

Air contoh yang sudah diambil ditambahkan $1 \mathrm{~mL} \mathrm{MnSO}_{4}$ dan $1 \mathrm{~mL}$ alkali iodida azida dengan ujung pipet tepat di atas permukaan larutan dan ditutup rapat dan segera dihomogenkan hingga membentuk gumpalan yang terlihat. Gumpalan dibiarkan mengendap 5 menit - 10 menit. Labu ditambahkan $1 \mathrm{~mL} \mathrm{H}_{2} \mathrm{SO}_{4}$ pekat perlahan dan ditutup serta dikoco hingga endapan larut secara homogen. Larutan dipipet $50 \mathrm{~mL}$ dituangkan dalam erlenmeyer $250 \mathrm{~mL}$ selanjutya dititrasi dengan larutan $\mathrm{Na}_{2} \mathrm{~S}_{2} \mathrm{O}_{3}$ menggunakan indikator amilum hingga terjadi perubahan warna larutan dari biru menjadi tepat bening (sesuai dengan SNI 06-6989.14-2004).

\section{Penentuan BOD}

Air contoh yang telah disiapkan dimasukkan dalam botol A1 dan A2 sampai air meluap keluar botol, kemudian botol segera ditutup dengan rapat untuk mencegah terbentuk gelembung udara. Botol selanjutnya dikocok dan ditambahkan air bebas mineral. Botol A2 disimpan ke dalam lemari inkubator $20^{\circ} \mathrm{C} \pm 1{ }^{\circ} \mathrm{C}$ selama 5 hari. Botol A1 diukur oksigen terlarutnya dengan metode tittrasi iodometri (sesuai dengan SNI 06-6989.14-2004). Hasil pengukuran merupakan nilai oksigen terlarut nol hari (A1). Penentuan nilai DO hari ke-0 harus dihitung paling lama 30 menit setelah pengenceran. Botol A2 yang telah diinkubasi 5 hari \pm 6 jam diukur kadar nilai DO sebagai kadar oksigen terlarut hari ke-5 (A2). Dengan cara yang sama dilakukan menggunakan larutan pengencer tanpa contoh air sebagai blanko atau B1 (nilai oksigen terlarut hari ke-0) dan B2 (nilai oksigen terlarut hari ke-5), serta menggunakan larutan glukosa-asam glutamat sebagai kontrol. Hasil pengukuran sebagai C1 (nilai oksigen terlarut hari ke-0) dan C2 (nilai oksigen terlarut hari ke-5) (sesuai dengan SNI 6989.72-2009).

\section{Penentuan COD}

Air contoh COD sebanyak $100 \mathrm{mg} / \mathrm{L}$ sampai dengan $900 \mathrm{mg} / \mathrm{L}$, merupakan air sampel yang sudah direfluks selanjutnya didinginkan perlahan hingga pada suhu ruang guna menghindati terbentuknya endapan. Pada proses pendinginan tutup air contoh dapat dibuka sesekali untuk menghindari terjadinya tekanan gas. Suspensi dibiarkan mengendap hingga didapatkan bagian yang jernih untuk pengukuran. Air contoh selanjutnya diukur serapannya pada 
panjang gelombang $600 \mathrm{~nm}$. Kadar COD ditentukan dari kurva kalibrasi dengan dilakukan secara duplo (sesuai dengan SNI 6989.2-2009).

\section{HASIL DAN PEMBAHASAN}

\section{Teknik Sampling}

Contoh air diambil di aliran Sungai Pengging daerah pembuangan limbah tahu tepatnya di titik 1 (pada jarak 25 meter sebelah barat dari sumber penampungan dan pembuangan limbah), titik 2 (pada jarak 0 meter dari sumber penampungan dan pembuangan limbah), dan titik 3 (pada jarak 25 meter sebelah timur dari sumber penampungan dan pembuangan limbah). Sampel titik 1 dipastikan jauh dari gangguan polutan organik dari limbah tahu sehingga dapat sebagai pembanding (sebagai acuan kondisi awal). Contoh air titik 2 merupakan tempat pembuangan polutan organik dari limbah tahu. Contoh air titik 3 merupakan zona aliran arus yang searah dan terdampak polutan organik dari limbah tahu. Contoh air diambil secara langsung dengan vial $1000 \mathrm{~mL}$ pada kedalaman kurang lebih $3 \mathrm{~cm}$ dari permukaan air dengan jarak $30 \mathrm{~cm}$ dari tepi sungai. Pilihan kedalaman dan jarak tersebut mempertimpangkan kedalaman sungai rata-rata sedalam $7 \mathrm{~cm}$.

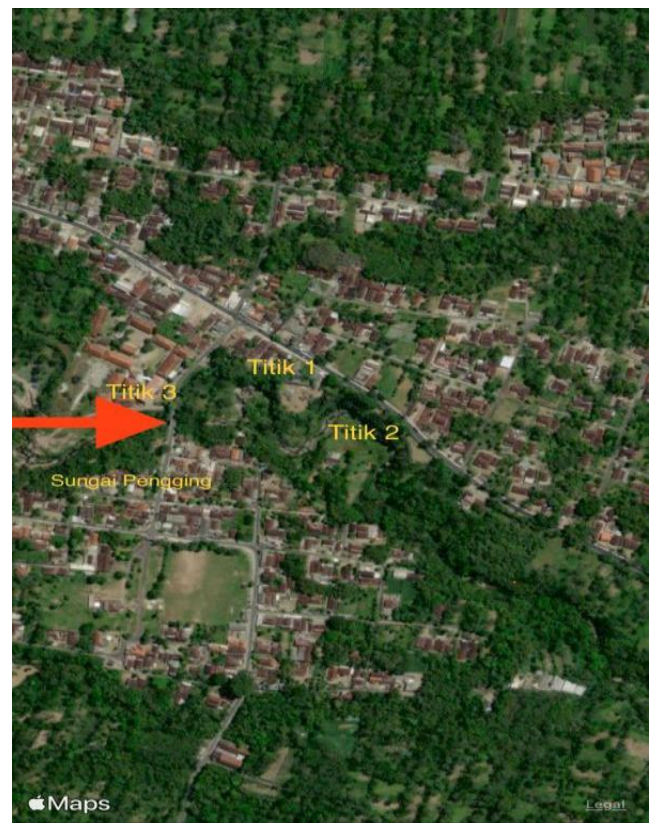

Gambar 1. Aliran Sungai Pengging 


\section{Penentuan Temperatur, pH dan Total Dissolved Solid (TDS) Contoh Air Aliran Sungai Pengging}

Temperatur dan $\mathrm{pH}$ menjadi parameter yang penting dalam menentukan kualitas air, karena mengindikasikan kemampuan biota perairan dalam melangsungkan ekosistemnya. Kelayakan baku mutu air juga ditentukan dari besarnya temperature dan $\mathrm{pH}$ air. Temperatur dan pH contoh air sungai diberikan pada Tabel 2 dan Tabel 3.

Tabel 2. Temperatur contoh air pada titik 1, titik 2, dan titik 3 yang diukur pada minggu ke-1, minggu ke-2 dan minggu ke-3

\begin{tabular}{l|ccl}
\hline \multirow{2}{*}{ Sampel } & \multicolumn{3}{c}{ Minggu ke- } \\
\cline { 2 - 4 } & $1\left({ }^{\circ} \mathrm{C}\right)$ & $2\left({ }^{\circ} \mathrm{C}\right)$ & $3\left({ }^{\circ} \mathrm{C}\right)$ \\
\hline Titik 1 & 27,80 & 28,65 & 28,95 \\
Titik 2 & 29,00 & 30,10 & 29,05 \\
Titik 3 & 28,60 & 29,40 & 28,90 \\
\hline
\end{tabular}

Berdasarkan Tabel 2, rata-rata contoh air pada ke-3 titik 1 mempunyai temperatur relatif tidak jauh berbeda $27,8-30,10{ }^{\circ} \mathrm{C}$. Namun demikian contoh air pada titik 2 telah sedikit lebih tinggi temperaturnya karena secara langsung terkena pembungan limbah sebagai aliran utama. Menurut Fardiaz (1992), bakteri dapat bekerja dengan baik pada temperatur yang meningkat hingga $40{ }^{\circ} \mathrm{C}$. Bakteri juga dapat melangsungan metabolismenya pada kondisi gelap dan tertutup. Temperatur ini masih memungkinkan bagi bakteri pengurai untuk mendekomposisi limbah tahu di mana jumlah protein dalam limbah sebanyak $65 \%$ dan sisanya terdiri dari karbohidrat dan lemak (Yudhistira, 2016). Besarnya pH contoh air dapat dilihat pada Tabel 3.

Tabel 3. pH contoh air pada titik 1, titik 2, dan titik 3 yang diukur pada minggu ke-1, minggu ke-2 dan minggu ke-3

\begin{tabular}{l|ccl}
\hline \multirow{2}{*}{ Sampel } & \multicolumn{3}{|c}{ pH Minggu ke- } \\
\cline { 2 - 4 } & 1 & 2 & 3 \\
\hline Titik 1 & 7,49 & 7,32 & 7,28 \\
Titik 2 & 7,18 & 7,06 & 6,44 \\
Titik 3 & 7,32 & 7,23 & 7,30 \\
\hline
\end{tabular}

Berdasarkan Tabel 3 diketahui $\mathrm{pH}$ contoh air sungai adalah $\mathrm{pH}$ 6,44 - 7,4 yang mengindikasikan bahwa limbah tahu telah bercampur dan mengalami pengenceran oleh air sungai sehingga masih memenuhi nilai baku mutu air menurut PP Nomor 82 Tahun 2001. Pada dasarnya limbah tahu relatif bersifat asam hingga $\mathrm{pH}$ 3-4 sebagai akibat kandungan asam cuka sisa dari proses pengumpalan dan perendaman tahu (Sepriani, 2016). Namun demikian, pH 
dalam lingkungan perairan dapat berubah dengan cepat adanya aliran air sungai yang secara dinamis bergerak dengan mengandung substrat yang heterogen.

Untuk mengetahui nilai TDS, dilakukan penentuan besarnya partikel terlarut pada contoh air sungai, dengan data diberikan pada Tabel 4 .

Tabel 4. Nilai TDS contoh air titik 1, titik 2, dan titik 3 yang diukur pada minggu ke-1, minggu ke-2 dan minggu ke-3

\begin{tabular}{l|lll}
\hline \multirow{2}{*}{\multicolumn{1}{c}{ Sampel }} & \multicolumn{3}{c}{ TDS Minggu ke- } \\
\cline { 2 - 4 } & \multicolumn{1}{c}{$1(\mathrm{mg} / \mathrm{L})$} & \multicolumn{1}{c}{$2(\mathrm{mg} / \mathrm{L})$} & $3(\mathrm{mg} / \mathrm{L})$ \\
\hline Titik 1 & 2,435 & 2,485 & 2,365 \\
Titik 2 & 10,957 & 8,335 & 3,580 \\
Titik 3 & 2,365 & 2,450 & 2,460 \\
\hline
\end{tabular}

Berdasarkan Tabel 4 mengindikasikan bahwa nilai TDS titik ke-2 paling tinggi. Hal ini karena letak titik ke-2 merupakan muara saluran pembuangan limbah tahu sehingga konsentrasi limbah dapat dipastikan lebih tinggi dari 2 titik pengambilan contoh yang lain. TDS merupakan padatan yang terurai dan terlarut di dalam air, TDS limbah tahu dapat berupa benda padat dari garam, mineral, logam, serta kation anion yang terlarut di air yang terukur dalam satuan parts per million (ppm) atau perbandingan rasio berat ion terhadap air. Nilai TDS berkaitan erat dengan tingkat kekeruhan air. Nilai TDS titik 2 yang lebih tinggi ini juga didukung oleh temperatur dan $\mathrm{pH}$ pada tititk ke-2 yang lebih tinggi pula sebagai akibat tempat yang paling banyak mengandung limbah tahu.

\section{Penentuan Dissolved Oksigen (DO) Contoh Air Aliran Sungai Pengging}

Oksigen terlarut atau DO merupakan salah satu parameter kimia karateristik air limbah tahu. Nilai DO menggambarkan jumlah oksigen yang dapat dimanfaatkan oleh organisme perairan. Nilai DO dari ke-3 posisi pengmabilan contoh air ditampilkan dalam Gambar 2.

Gambar 2 menunjukkan bahwa nilai DO titik 2 relatif paling rendah, hal ini mengindikasikan pencemaran yang tinggi sebagai akibat komposisi limbah organik dari ampas tahu seperti protein, karbohidrat dan lemak. Suatu perairan dikatagorikan tercemar apabila memiliki kandungan oksigen relatif rendah sedangkan populasi bakterinya cukup tinggi. Aktivitas bakteri dalam limbah tahu dalam melakukan biodegradasi cukup tinggi melalui reaksi 
oksidasi limbah organiknya, sehingga kebutuhan oksigen di dalam air semakin menurun dan menyebabkan oksigen terlarut semakin sedikit. Hasil ini sebagaimana yang dilaporkan oleh Sepriani (2016) di mana populasi bakteri dalam perairan berkaitan dengan aktifitas biologisnya dalam menguraikan limbah organik yang dapat terjadi secara alamiah.

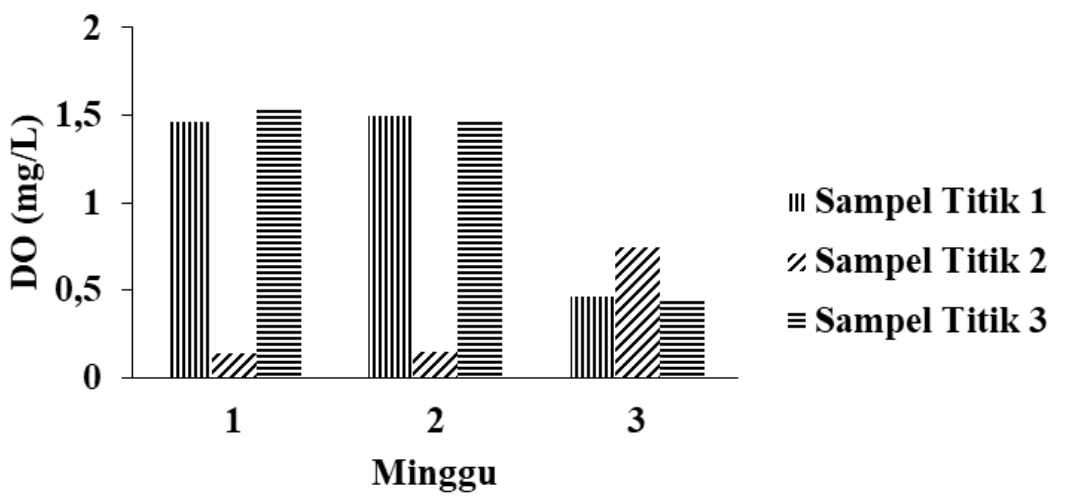

Gambar 2. Nilai DO contoh air pada titik 1, titik 2, dan titik 3 Sungai Pengging

\section{Penentuan Biochemical Oxygen Demand (BOD) Contoh Air Aliran Sungai Pengging}

Kebutusan oksigen untuk aktivitas mikroorganisme merupakan parameter yang penting dalam mengevaluasi jumlah senyawa organik terlarut. Hal ini menunjukkan jumlah oksigen yang dibutuhkan oleh mikroorganisme dalam menguraikan zat organik secara biologis didalam air limbah (Adeko, 2018). Nilai BOD diberikan dalam Gambar 3.

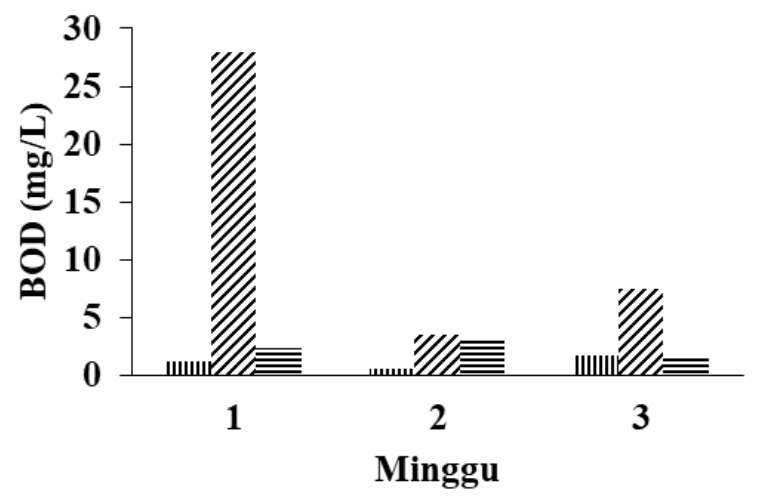

III Sampel Titik 1

" Sampel Titik 2

=Sampel Titik 3

Gambar 3. Nilai BOD contoh air pada titik 1, titik 2, dan titik 3 Sungai Pengging 
Berdasarkan Gambar 3 menunjukkan bahwa nilai BOD contoh air pada titik 2 memiliki nilai BOD tertinggi karena menjadi muara pembuangan saluran limbah tahu. Nilai BOD yang tinggi menggambarkan terjadi reaksi biodegradasi yang cukup tinggi pula akibat kandungan senyawa organik yang melimpah di titik ini. BOD yang tinggi menunjukkan kebutuhan oksigen bagi mikroorganisme untuk menguraikan limbah cukup banyak sehingga biota air dapat kekurangan oksigen akibat kebutuhan oksigen terserap oleh mikroorganisme. Nilai BOD yang tinggi mengindikasikan telah terjadi pencemaran.

Secara umum, nilai BOD pada sampel titik 1 dan 3 masih memenuhi standar baku mutu kelas I menurut PP No.82 Tahun 2001. Hal ini berkaitan dengan cukup rendahnya limbah organik di kedua titik tersebut. Rendahnya limbah organik menunjukkan kebutuhan oksigen terlarut (DO) relatif tinggi, sehingga aktivitas biodegradasi oleh bakteri relatif rendah pula.

\section{Penentuan Chemical Oxygen Demand (COD) Contoh Air Aliran Sungai Pengging}

Kebutuhan oksigen kimia (COD) adalah banyaknya oksigen yang dibutuhkan oleh mikroorganisme dalam menguraikan senyawa kimia dalam air melalui reaksi oksidasi (Adeko, 2018). Jika kadar senyawa organik dan anorganik cukup besar, maka oksigen yang terlarut di dalam perairan dapat mencapai nol sehingga biota air seperti tumbuhan air, ikan-ikan dan hewan air lainnya akan kekurangan oksigen untuk melangsungkan hidupnya. Nilai COD diberikan dalam Gambar 4.

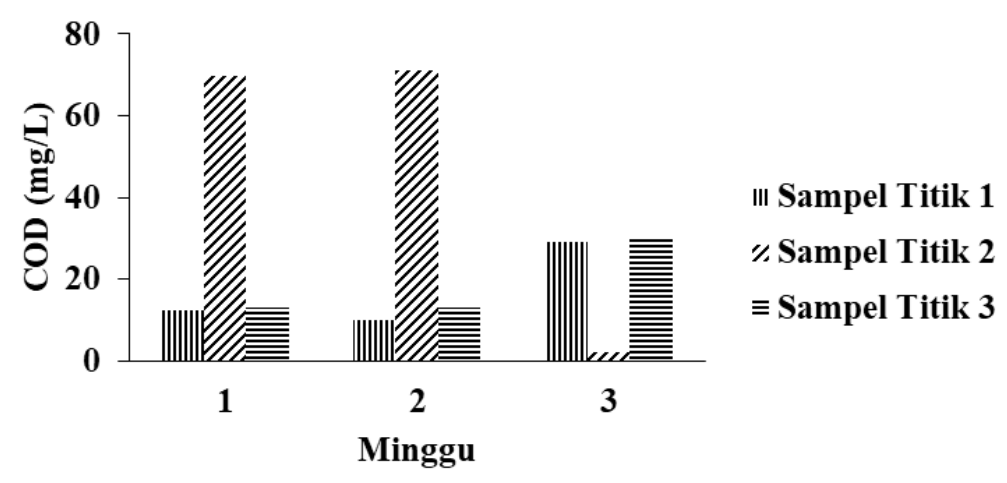

Gambar 4. Nilai COD contoh air pada titik 1, titik 2, dan titik 3 Sungai Pengging

Gambar 4 menunjukkan bahwa nilai COD tertinggi terjadi di titik 2. Hal ini berbanding lurus dengan nilai BOD tertinggi juga terjadi pada contoh air di titik 2. Kondisi COD yang 
tinggi mengindikasikan limbah organik cukup banyak yang mengalami oksidasi oleh mikroorganisme sehingga kualitas perairan semakin rendah. Nilai COD seringkali lebih tinggi daripada nilai BOD karena beberapa senyawa organik seperti selulosa relatif sulit teroksidasi secara biokimia sehingga tidak terukur dengan metode penentuan BOD, tetapi oksidasi selulosa lebih mudah terjadi melalui reaksi kimia sehingga dapat terukur dengan metode penentuan COD (Fardiaz, 1992). Selulosa dan beberapa senyawa organik dapat dihasilkan dari air hasil rendaman dan pengelupasan kulit kedelai yang masih banyak mengandung pati (Yudhistira, 2016).

\section{KESIMPULAN}

Berdasarkan penentuan parameter kualitas air pada sakuran pembuangan limbah tahu di Sungai Pengging, maka didapatkan kesimpulan sebagai berikut:

- Contoh air pada pengambilan titik 2 di mana berada tepat pada muara pembuangan limbah relatif memiliki tingkat pencemaran lebih tinggi daripada 2 titik tempat pengambilan contoh air yang lain.

- Parameter pencemaran pada titik 2 diindikasikan oleh temperatur air lebih tinggi (29,05$\left.30,1{ }^{\circ} \mathrm{C}\right)$, nilai TDS yang lebih tinggi $(8,33-10,95 \mathrm{mg} / \mathrm{L})$, nilai COD dan BOD lebih besar (71,5 dan 28,2 mg/L), serta nilai DO paling kecil $(0,11-0,16 \mathrm{mg} / \mathrm{L})$.

\section{DAFTAR PUSTAKA}

Adeko, A., Widada, A., 2018, Efektifitas Pengolahan Limbah Cair Industri Tahu dengan Metode Aerasi untuk Menurunkan Kadar BOD, Journal of Nursing and Public Health., 6, 1.

Badan Standardisasi Nasional (BSN)., 2004, SNI 06-6989.14-2004. Oksigen Terlarut, BSN, Jakarta.

Badan Standardisasi Nasional (BSN)., 2008, SNI 6989.57-2008. Metode Pengambilan Contoh Air Permukaan, BSN, Jakarta.

Badan Standardisasi Nasional, (BSN)., 2009, SNI 6989.2-2009. Cara uji Kebutuhan Oksigen Kimiawi COD, BSN, Jakarta.

Badan Standardisasi Nasional, (BSN)., 2009, SNI 6989.72-2009. Cara Uji Kebutuhan BOD, BSN, Jakarta.

Fardiaz, S., 1992, Polusi Air dan Udara, Kanisius, Yogyakarta. 
Febrian, S. B., Vian, J.P., Wenny, T. K., Deanne, A., 2020, Analisis Kandungan Limbah Industri Tahu dan Tempe Rahayu di Kelurahan Uner Kecamatan Kawangkoan Kabupaten Minahasa, Agri-SosioEkonomi Unsrat., 16, 2, 245 - 252.

Nurhasan dan Pramudyanto., 1991, Penanganan Air Limbah Pabrik Tahu, Yayasan Bina Karya Lestari, Semarang.

Pradana, T.D., Suharno, Apriansyah., 2018, Pengolahan Limbah Cair Tahu untuk Menurunkan Kadar TSS dan BOD, Jurnal Vokasi Kesehatan., 4, 2, 56-62.

Peraturan Pemerintah Republik Indonesia., 2001, Peraturan Pemerintah Republik Indonesia Nomor 82 Tahun 2001 Tentang Pengelolaan Kualitas Air dan Pengendalian Pencemaran Air, Jakarta.

Sepriani, Abidjulu, J., Harry S.J., Kolengan., 2016, Pengaruh Limbah Cair Industri Tahu terhadap Kualitas Air Sungai Paal 4 Kecamatan Tikala Kota Manado, Chem. Prog., 9, 1.

Yudhistira, B., Andriani, M., Rohula, U., 2016, Karakterisasi Limbah Cair Industri Tahu Dengan Koogulan yang Berbeda (Asam Asetat dan Kalsium Sulfat), Journal of Sustainable Agriculture., 31, 2, 137-145. 